\title{
Granular Bioactive Formulation of Trichoderma viride and Arbuscular Mycorrhizal Fungi for Biological Control of Cumin Wilt Disease
}

\section{Ghoneem, K.M.; Khalil, A.A.; Rashad, E.M.; Ahmed, M.I.M.; Mahmoud, M.S.M.}

\author{
Seed Pathology Research Department, Plant Pathology \\ Research Institute, Agricultural Research Center, Giza, \\ Egypt.
}

Cumin wilt caused by Fusarium oxysporum f. sp. cumini is the most destructive abundant disease, limiting the cumin production in Egypt. The objective of this study was to evaluate the efficacy of granular bioactive formulation of Trichoderma viride (GBTV) and arbuscular mycorrhizal fungi (AM) for biological control of cumin wilt disease. Ten Trichoderma species were isolated from the rhizosphere of healthy cumin plants and tested in dual culture assay against the growth of $F$. oxysporum. Trichoderma viride TC40, $T$. hamatum and T. koningii recorded the highest reduction in the growth of the target pathogen. Under greenhouse conditions, use of AM+GBTV formulation minimized $F$. oxysporum incidence and increased plant survival percentages. GBTV treatment alone came the second when compared to infected control. The greatest proportional increases in cumin plant growth were elicited by GBTV formulation and/or AM treatments. The highest level of mycorrhizal root colonization was noticed in the presence or absence of the pathogen. The biochemical parameters of the infected plants with AM or by GBTV treatment showed a pronounced increase in the plant content of total phenols, peroxidase and polyphenoloxidase activities. Under field conditions, AM+GBTV treatment highly reduced disease incidence of wilt symptoms and increased plant survival as equal as chemical fungicide. It also improved plant growth parameters and yield. The suggested formula is highly recommended for Fusarium wilt management and yield production of cumin plants.

Keywords: Fusarium wilt, Trichoderma bioformulation, Arbuscular Mycorrhiza, cumin

The annual herbaceous spice medicinal plant Cumin (Cuminum cyminum L.) belongs to family Apiaceae. The plant is believed to be a native of the Mediterranean and Near Eastern regions (Deepak et al., 2008). Uses of cumin seeds are numerous such as cooking, desserts, cosmetics, perfumes and therapeutic medicine. The typical pleasant aroma of the seeds is due to their volatile oil content, the principal constituent of which is cuminaldehyde (Verma et al., 2018).

Cumin crop suffers from a number of diseases. Among the major threats to the cumin is wilt disease caused by Fusarium oxysporum f. sp. cumini Patel, Prasad 
Mathur and Mathur. The disease is one of the most limiting factors for cumin production in several plant growing areas (Tawfik and Allam, 2004 and Bhatnagar et al., 2013). The pathogen is soil and seed-borne under severe conditions, up to 70$80 \%$ crop losses were observed in many fields. It causes under soil infection, the pathogen is able to produce fungal chlamydospores survive in soil up to 6 years even with the absence of the host plant, which complicates control (Haware et al., 1996). Because of their efficiencies, chemical fungicides are extensively used for the management of cumin diseases, however it may gradually developes resistance and potential hazards may also extend to non-target organisms and the surrounding environment as well as, and the human health. Therefore, the biological control using bio agents became a proper alternative option (Harman, et al., 2004 and Mahmoud, 2017).

The genus Trichoderma includes prevalent soil-borne fungi with well-known diverse anti-phytopathogen activities, global distribution and reproductive potentiality. Mechanisms of action include rivalry for space and/or nutrients, antibiosis, mycoparasitism, antibiosis, and host-induced systemic resistance (Ghorbanpour et al., 2018), synthesizing a large set of enzymes like cellulases, amylases, lipases and pectinases, as well as secondary metabolites such as siderophores (Harman et al., 2004). Granular formulation of Trichoderma is a unique among other types of formulations because of its long viability as well as easy to be used by the farmers. Therefore, it can be applied in the field (Bharti et al., 2017).

Arbuscular Mycorrhizal Fungi (AMF) are soil fungi, obligate endophytes that live in mutualism with roots of $80 \%$ of the vascular plants (Kehri et al., 2018). AMF are found in all terrestrial ecosystems with varied extent of $\mathrm{pH}$, salinity, organic matter, and environmental conditions. AMF improve the plant growth and metabolic processes, increases the resistance to drought, salinity, heavy metals, as well as enhances the immunity against various pathogenic mycobiota (Chen et al., 2018). Many fungal pathogens have been extensively bio controlled by AMF. (Tanwar et al., 2013 and Zhang et al., 2018). The biocontrol mechanisms exerted by AMF comprise direct rivalry with other soil-borne pathogenic fungi for nutrients, space, and colonization sites, changing of the soil microbial composition in the rhizosphere area. AMF may indirectly decrease the losses resulting from the disease by damage compensation, growth improvement and triggering the plant immunity against the phytopathogen attack (Hafez, et al., 2013). Abdel-Fattah et al. (2011) reported triggering multiple defense-related reactions in bean plants against infection with Rhizoctonia root rot as a result of application of AMF.

Herein, a novel strategy was planned to evaluate the efficacy of AM and a granular bioactive formulation of Trichoderma (GBTV), individually and in combinations, for controlling Fusarium wilt disease under greenhouse and field

Egypt. J. Phytopathol., Vol. 47, No. 1 (2019) 
conditions. Also, study their role in enhancing growth, physiological activities and yield of cumin plants.

\section{Materials and Methods}

The Causal organism and Trichoderma species:

The pathogenic fungus $F$. oxysporum was isolated from naturally diseased cumin roots exhibiting typical symptoms of wilt disease obtained from the growing fields of Ismailia Agricultural Research Station, ARC, Ismailia Governorate. The fungus was isolated on potato dextrose agar (PDA) plates (Difco, USA), supplemented with chloramphenicol $(5 \mathrm{mg} / \mathrm{L})$ and streptomycin sulphate $(5 \mathrm{mg} / \mathrm{L})$ and incubated at $25 \pm 2{ }^{\circ} \mathrm{C}$ for 5-7 days. Hyphal tip technique was used to obtain pure cultures of the isolated fungal pathogen. The recovered isolates were maintained onto slants of potato carrot agar medium and kept at $4{ }^{\circ} \mathrm{C}$ for further studies. The isolated fungi were identified according to their cultural, morphological and microscopically characteristics as described by Booth (1977); Domsch et al. (1980) and Watanable (2002).

The collected rhizospheric soil samples of healthy cumin plants were used to isolate Trichoderma species using a selective medium of Elad et al. (1991). The developed colonies were transferred onto PDA slants and identified after growing them on malt extract agar for two days at $25^{\circ} \mathrm{C}$ according to Bissett (1991) and Kubicek and Harman (2002). The identification was confirmed at the Mycological Center, Assiut University (AUMC), Egypt.

Antifungal activity of Trichoderma spp. In Vitro using dual culture assay:

The antagonistic potential of ten Trichoderma spp. isolated from rhizosphere soil of healthy cumin plants grown in Ismailia governorate was evaluated against $F$. oxysporum f.sp. cumini (FOC) using dual culture technique (Dhingra and Sinclair, 1995). Five-mm mycelial disc in diameter of 5-days old culture of the antagonistic fungi was paired against the same sized mycelial disc of FOC at the opposite end on $9 \mathrm{~cm}$ diameter PDA Petri- plates. The pathogen and antagonist discs were placed at equal distances from the periphery of the Petri plate. The PDA plates inoculated only with either antagonists or phytopathogen served as control. All plates were incubated at $25 \pm 2^{\circ} \mathrm{C}$ until FOC completely covered the PDA surface of the control treatment. The inhibition percentage of radial growth of the pathogen was calculated according to the following equation:

$$
\text { Inhibition }(\%)=(\mathrm{R} 1-\mathrm{R} 2) / \mathrm{R} 1 \times 100
$$

Where: $\mathrm{R} 1$ = radial growth of the pathogen in the control, $\mathrm{R} 2=$ radial growth of the pathogen in dual culture (with the antagonist).

The antagonism reaction of Trichoderma spp.:

Based on the previous screening, the antagonism potentiality of Trichoderma isolate was evaluated using a scale of 1 to 5 after the $8^{\text {th }}$ day of dual growth

Egypt. J. Phytopathol., Vol. 47, No. 1 (2019) 
according to (Bell et al., 1982), where, 1=Trichoderma overgrowing pathogen, and $5=$ pathogen overgrowing Trichoderma . Pathogens developed from plates of dual cultures were then microscopically investigated and the changes in the mycelium of the pathogen were recorded.

The most effective isolate of Trichoderma was identified on malt extract agar (Kubicek and Harman, 2002) and the identification was confirmed at Assiut University Mycological Centre (AUMC), Egypt.

Greenhouse experiment:

The effect of the formulated $T$. viride and/or arbuscular mycorrhizal fungi (AM) was evaluated against $F$. oxysporum under greenhouse conditions.

\section{Inoculum preparation}

\section{Preparation of $T$. viride formula}

The inoculum of $T$. viride was prepared using 14 days old culture grown on potato dextrose broth under static conditions as active ingredients. The flask content was put on a blender and blended at $150 \mathrm{rpm}$ for $15 \mathrm{~min}$. The concentration was adjusted to $2.5 \times 10^{7}$ spores $/ \mathrm{ml}$ using a haemocytometer slide. To produce one $\mathrm{kg}$ of formulation, $625 \mathrm{ml}$ of the whole culture mixed with $161 \mathrm{~g}$ kaolin (Merk) and $1500 \mathrm{~g}$ semolina, were blended well with water if needed. The dough was then rolled through a small hand-operated bread machine into sheets, which were folded and extruded 10-15 times at different roller gap settings until it became homogeneous. The dough sheets were then extruded, without refolding, at a narrow gap to yield a one $\mathrm{mm}$ thick sheet. The sheets were then placed on aluminum foil and air-dried at ambient laboratory conditions $\left(25 \pm 2^{\circ} \mathrm{C}\right)$. The dried sheets were ground in a grinder into granules and sieved to specific sizes (2.30 to $2.80 \mathrm{~mm}$ ).

\section{Preparation of AMF inoculum}

A mixture of AM, kindly provided by Prof. Dr. Gamal Abdel-Fattah, professor of Microbiology, Botany Department, Faculty of Science, Mansoura University, was used. The mixture consists of equal proportions of spores of Glomus mosseae, Glomus clarum and Glomus aggregatum in suspension format at $1 \times 10$ unit $\mathrm{L}^{-1}$. The mass inoculum was prepared using the pot culture technique on Sudan grass as a host plant. Spores of the previous formula were inoculated on surface-sterilized ( $10 \%$ sodium hypochlorite for $30 \mathrm{~min}$.) sudan grass seeds, which were sown in plastic pots (40 cm diameter), containing previously sterilized sandy loam soil (two successive cycles each of $121^{\circ} \mathrm{C}$ for $30 \mathrm{~min}$ ). The plants were grown in the greenhouse $\left(25-30^{\circ} \mathrm{C}\right)$ with a transparent plastic roof and open sides. No fertilizer or any chemical was applied to soil. Thirty days after planting, the sudangrass plants were cut above the soil surface and the soil was dried in the pot, then crushed by hand and used as AM inoculum.

Egypt. J. Phytopathol., Vol. 47, No. 1 (2019) 
Preparation of $F$. oxysporum inoculum

Inoculum of $F$. oxysporum was prepared by growing on potato dextrose agar plates and incubated at $\left(25 \pm 2^{\circ} \mathrm{C}\right)$ for five days then mycelium plugs were carried on sterilized medium of sorghum: coarse sand: water $(2: 1: 2 \mathrm{v} / \mathrm{v})$ and incubated at room temperature for ten days; to be ready to use.

\section{Greenhouse evaluation of GBTV and/or AM on cumin}

Pots were filled with $5 \mathrm{~kg} / \mathrm{pot}$ disinfected soil; clay: sand $(2: 1, \mathrm{v} / \mathrm{v})$ and singly infested with the previously prepared pathogens inoculum at the rate of $0.3 \%(\mathrm{w} / \mathrm{w})$, then regularly watered to near field capacity with tap water and left for one week to guarantee the spread of the fungus. AM was used for inoculation at $40 \mathrm{~g} / \mathrm{pot}$ while GBTV was used at $1.5 \mathrm{~g} /$ pot. Chemical fungicide $(\mathrm{F})$ used through the present investigation as a positive control was Rizolex-T (50\% WP). Dosage, used as recommended by the Ministry of Agriculture, was $3 \mathrm{~g} / \mathrm{kg}$ seeds "Balady" and applied as a seed dressing. The treatments applied were;

(1) Negative control without any treatment, (2) Arbuscular mycorrhiza (AM), (3) Granular Bioactive $T$. viride formulation (GBTV), (4) F. oxysporum pathogen $(\mathrm{P})$, (5) $\mathrm{P}+\mathrm{AM}$, (6) P + GBTV, (7) P + recommended fungicide (F), and (8) P + GBTV + AM. All pots were arranged in a randomized block design and kept in the greenhouse.

Disease assessment

Un-emerged seeds were recorded after 20 days, while percentage of dead seedlings and survived plants were recorded after 45 days from planting.

\section{Growth parameters}

Five plants of each treatment were carefully recovered after 60 days from the pathogen inoculation, rinsed with running water to remove any particles of soil and the following parameters were recorded: plant height $(\mathrm{cm})$, numbers of branches and leaves, number of umbels, fresh and dry weights $(\mathrm{g})$ of the plant.

\section{Staining of AM infection root}

Samples of 56-days of cumin roots were gently pulled at the end of the greenhouse experiment. Roots were washed several times with tap water to remove all the remaining soil particles, then cut into small segments $(0.5-1.0 \mathrm{~cm})$ and heated at $90{ }^{\circ} \mathrm{C}$ for $45 \mathrm{~min}$. in $10 \% \mathrm{KOH}$ to remove host cells cytoplasm and nuclei. After that, root segments were rinsed in tap water and stained with $0.05 \%$ trypan blue (Sigma) in lactophenol (Phillips and Hayman, 1970) for $15 \mathrm{~min}$. at $90^{\circ} \mathrm{C}$. Then washed by tap water to remove the excess stain. Forty randomly selected root pieces were mounted on slides in lactoglycerol and examined microscopically for the determination of the degree of AM root colonization (Trouvelot et al., 1986).

Evaluation of some physiological activities in cumin plants:

At 28 days of plant growth, extraction and activity of both polyphenoloxidase and peroxidase enzymes were determined using a spectrophotometric method 
according to Seleim et al. (2014). Total phenolic contents of fresh leaves were determined by using the Folin-Ciocalteu reagent method according to Blainski et al. (2013). After 60 days, total chlorophyll, chlorophyll a, chlorophyll b and carotene in cumin leaves were determined according to Robinson and Britiz (2000).

\section{Field experiment:}

The experiment was carried out under field conditions at Ismailia Agricultural Research Station, ARC, Ismailia Governorate, Egypt during the summer season (2018). The same treatments previously carried out in the greenhouse were reapplied under field conditions under natural infection to study some growth parameters and yield components of cumin plants. Plots (each $3 \times 6 \mathrm{~m}^{2}$ ) were plowed well, all weeds were removed and soil was leveled, dissected to lines. Ammonia nitrate $\left(15.5 \%, \mathrm{P}_{2} \mathrm{O}_{3}\right)$ and potassium sulfate $\left(48 \%, \mathrm{~K}_{2} \mathrm{O}\right)$ were applied at recommended doses. For soil treatment, GBTV formulation and/or AM mixture at levels of $67.5 \mathrm{~g}$ and $1800 \mathrm{~g} / 18 \mathrm{~m}^{2}$, were applied. The inocula of bio-agents were ground and finally mixed with soil at the time of seed sowing. Cumin seeds "Balady" were planted in hills $5 \mathrm{~cm}$ apart on one side of row ridge. After planting, the soil was ridged up around the plants, either along rows or around individual plants as hills. All plots with three replicates were arranged in a randomized block design.

Evaluation of growth parameters and yield components of cumin:

During the flowering stage, ten cumin plants were randomly selected and plant height, number of branches and dry weight of the plants were measured. During the harvest stage, umbels number, weight of seeds per plant and weight of 1000 seed were determined as yield parameters.

\section{Statistical analysis}

The statistical analysis software; CoStat version 6.4 (CoHort Software) was used for the analysis of variance (ANOVA) of the data, comparison among means was carried out using Duncan's new multiple range test at probability (P) level $\leq 0.05$ (CoStat, 2005).

\section{Results and Discussion}

\section{Dual culture assay:}

Ten Trichoderma isolates obtained from the rhizosphere of healthy cumin plants were tested in dual culture assay against growth of FOC. All Trichoderma isolates strongly inhibited the growth of the target pathogen, with different degrees. $T$. viride isolate TC40, T. hamatum and T. koningii recorded the highest reduction of FOC pathogen (66.76, 65.0 and 61.67\%, respectively). All isolates had an antagonism reaction of (1) except $T$. atroviride. The best antagonism reaction (1) was recorded of $T$. viride isolate TC40 on $F$. oxysporum, which was sporulated over the colonies of the target pathogen (Table 1 and Fig. 1). So, it was selected for further studies. Similar trends of the results were observed in the findings of Aghnoom et al. (2002)

Egypt. J. Phytopathol., Vol. 47, No. 1 (2019) 
and Deepak et al. (2008) who reported T. harzianum as a potential antibiosis and hyper-parasitism against Fusarium wilt of cumin. Also, Abhiram and Masih (2018) screened the antagonistic ability of Trichoderma viride against $F$. oxysporum strains under in vitro conditions. They revealed that, $T$. viride strongly retarded the growth of target pathogen strains, with different degrees ranging from 14.72 up to $71.00 \%$ in sealing agar plate method.

High degree of antagonism reaction observed in Table 1 \& Fig. 1 means the occurrence of strong mycoparasitism. Trichoderma species were found to produce inhibition zones and cover the colonies with the sporulation of it by different degrees. Mycoparasitism is the major antagonistic mechanism displayed by Trichoderma spp., which can attach to and surround by the pathogen, in some cases, form appressoria on the host surface, wherein, Trichoderma spp. produce many cell wall degrading enzymes and may be antibiotics that result in parasitism and dissolve of the cell walls, which act as a direct entry of Trichoderma hyphae into the pathogen (Vinale et al., 2014; Mohamed, 2017 and El-Gazzar, et al., 2018). In this respect, Monteiro et al. (2010) showed that T. harzianum ALL42 was able to completely inhibit $R$. solani and $M$. phaseolina mycelia, by surrounding around the hyphae with the formation of appressoria and hook-like structures. Similar result was obtained by Gajera et al. (2012) who indicated that T. koningi MTCC 796 and $T$. harzianum NABII were capable of overgrowing and degrading M. phaseolina mycelia, coiling around the hyphae with apressoria and hook-like structures. as well as secreat a cell wall degrading enzymes like chitinase, $\beta-1,3$ glucanase, protease and cellulase.

Table (1): Growth of cumin F. oxysporum as affected by Trichoderma spp. in a dual culture test

\begin{tabular}{lcc}
\hline \multicolumn{1}{c}{ Trichoderma isolates } & Growth reduction $(\%)$ & Antagonism reaction \\
\hline T. asperellum & $57.50 \mathrm{bc}$ & 1 \\
$T$. atroviride & $55.83 \mathrm{c}$ & 2 \\
$T$. hamatum & $65.00 \mathrm{a}$ & 1 \\
$T$. harzianum TC1 & $43.33 \mathrm{e}$ & 1 \\
$T$. harzianum TC30 & $59.17 \mathrm{bc}$ & 1 \\
$T$. harzianum TC5 & $42.50 \mathrm{e}$ & 1 \\
$T$. koningii & $61.67 \mathrm{ab}$ & 1 \\
$T$. viride TC18 & $49.17 \mathrm{~d}$ & 1 \\
$T$. viride TC20 & $54.17 \mathrm{~cd}$ & 1 \\
$T$. viride TC40 & $66.67 \mathrm{a}$ & 1 \\
\hline
\end{tabular}

Means followed by the different letter within each column are significantly different using Duncan's Multiple Range Test at P-value of $\leq .0 .05$ 


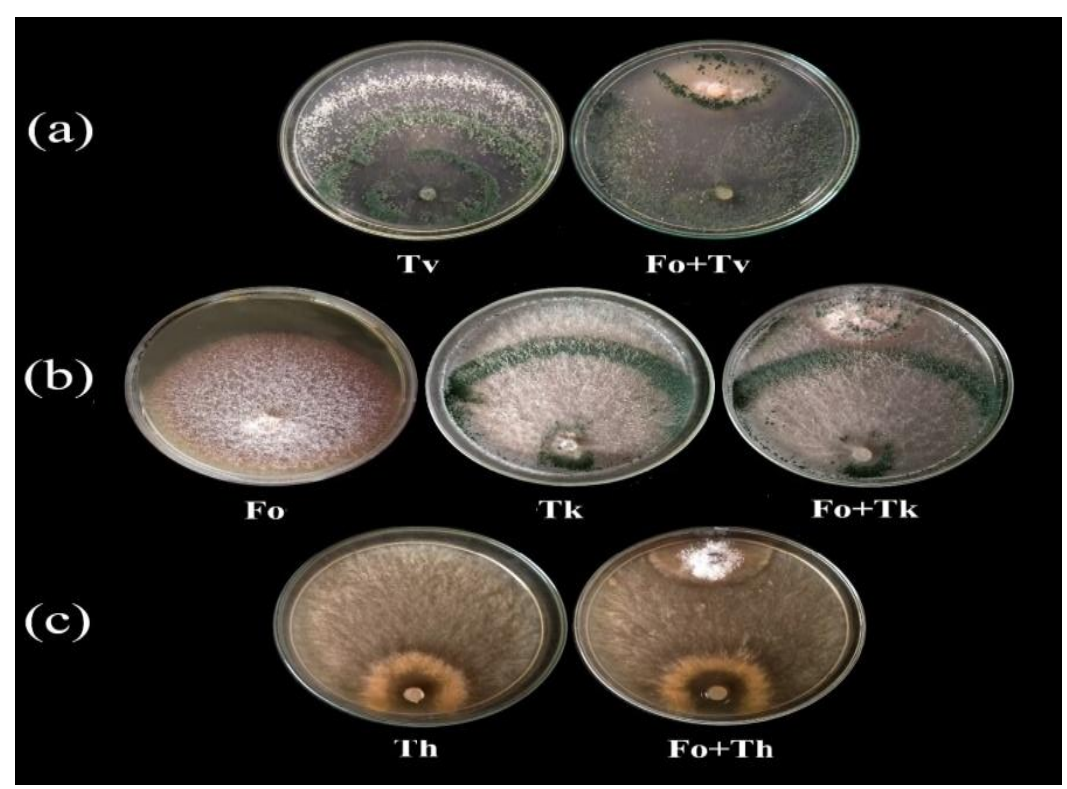

Fig. 1: Dual culture test of three individual Trichoderma spp. against Fusarium oxysprum f. sp. cumini showing overgrowth of Trichoderma spp. after 8 days incubation, (a) T. viride TC40, (b) T. koningii, and (c) T. hamatum. Where, Fo: $F$. oxysprum, Tv: T. viride, Fo+Tv: F. oxysprum and T. viride, Tk: T. koningii, Fo+Tk: $F$. oxysprum and $T$. koningii, Th: T. hamatum, and Fo+Th: $F$. oxysprum and $T$. hamatum.

Greenhouse experiment

Data presented in Table (2) show a significant $(\mathrm{P} \leq .0 .05)$ reduction in percentage of FOC infection either on seeds or at seedling stage as a result of (GBTV) and/or (AM) treatment. Moreover, such disease reduction, however was greatly marked when GBTV combined with AM (10.5 \& 8.7\%), followed by GBTV (13.2 \& 8.7\%) and $\mathrm{AM}(15.5 \& 11.7 \%)$ and $\mathrm{P}+\mathrm{F}(17.0 \& 12.0 \%)$, respectively.

In return, the obtained results clearly indicate that the percentage of cumin plants was increased significantly in dual $(\mathrm{GBTV}+\mathrm{AM})$, followed by sole treatment (GBTV, AM, F) either in cumin plant infected or uninfected with FOC pathogen.

Effect on growth parameters:

Biotreatments with GBTV and AM enhanced growth parameters of cumin plants over the control either infected or uninfected plants with wilt disease caused by FOC (Table 3). Dual application with GBTV plus AM exceeded that of single application GBTV or AM in this respect. On the other side, it was noted that increases in most growth features of cumin plant did not reach to the significant level especially in the number of umbles (the most economical part of cumin crop).

Egypt. J. Phytopathol., Vol. 47, No. 1 (2019) 
The obtained results are in agreement with Tanwar et al. (2013) who reported appreciable results in increasing growth parameters of tomato plants due to the combined inoculation of AM and T. viride under infection stress of Fusarium wilt pathogen. These results were confirmed also by the work of Al-Askar et al. (2014) and Ezzat et al. (2015). They reported a significant improvement in almost all vegetative growth and tuber yield parameters of Jerusalem artichoke plants due to the use of a mixture of AM and the Trichoderma species (in mixture) or antioxidant hydroquinone under natural conditions. The pronounced positive effects on the vegetative growth parameters of plants may be attributed to the fact that plants under inoculation with $\mathrm{AM}$ increased utilization of water and nutrients, particularly phosphorus, and that in turn, enhanced the vegetative growth. AM takes up a significant fraction of all plant photosynthetically fixed carbon, while the mycorrhizal plant obtains nutrients, such as inorganic phosphate via the AM hyphae (Pérez-de-Luque et al., 2017; Chen et al., 2018). The inoculation with AM can improve plant growth and biomass accumulation of bioenergy crops (Galega orientalis and Helianthus tuberosus) even in non-sterile soil containing naturally occurring AM, that is why more than $80 \%$ of vascular plant families are capable of forming the AM symbiosis (Van der Heijden and Sanders, 2002).

Table (2): Influence of GBTV, AM treatments or their combinations on the development of $F$. oxysporum wilt of cumin under greenhouse conditions

\begin{tabular}{ccccc}
\hline & Treatment & Seed rot\% & $\begin{array}{c}\text { Infected } \\
\text { seedling\% }\end{array}$ & $\begin{array}{c}\text { Plant } \\
\text { survival \% }\end{array}$ \\
\hline \multirow{2}{*}{$\begin{array}{c}\text { Non- } \\
\text { Infected }\end{array}$} & $\mathrm{C}$ & $7.250 \mathrm{e}$ & $2.500 \mathrm{c}$ & $90.25 \mathrm{~b}$ \\
& AM & $3.500 \mathrm{f}$ & $1.750 \mathrm{c}$ & $94.75 \mathrm{a}$ \\
& GBTV & $3.500 \mathrm{f}$ & $2.000 \mathrm{c}$ & $94.50 \mathrm{a}$ \\
& $\mathrm{AM}+$ GBTV & $3.500 \mathrm{f}$ & $1.250 \mathrm{c}$ & $95.25 \mathrm{a}$ \\
\hline \multirow{3}{*}{ Infected } & $\mathrm{P}$ & $25.00 \mathrm{a}$ & $13.50 \mathrm{a}$ & $61.50 \mathrm{f}$ \\
& $\mathrm{P}+$ AM & $15.50 \mathrm{bc}$ & $11.75 \mathrm{ab}$ & $72.75 \mathrm{e}$ \\
& $\mathrm{P}+$ GBTV & $13.25 \mathrm{~cd}$ & $8.750 \mathrm{~b}$ & $78.00 \mathrm{~d}$ \\
& $\mathrm{P}+\mathrm{F}$ & $17.00 \mathrm{~b}$ & $12.00 \mathrm{ab}$ & $71.00 \mathrm{e}$ \\
& P+AM+ GBTV & $10.50 \mathrm{de}$ & $8.750 \mathrm{~b}$ & $80.75 \mathrm{c}$ \\
\hline
\end{tabular}

Means followed by the different letter within each column are significantly different using Duncan's Multiple Range Test at $P$ value of $\leq .0 .05$

Where; $\mathrm{C}=$ negative control, $\mathrm{AM}=$ arbuscular mycorrhiza, $\mathrm{GBTV}=$ granular formulated $T$. viride, $\mathrm{P}=$ Fusarium oxysporum pathogen and $\mathrm{F}=$ Recommended fungicide 
Table (3): Cumin growth as influenced by GBTV and/or AM treatments under greenhouse conditions

\begin{tabular}{|c|c|c|c|c|c|c|c|c|}
\hline & reatment & 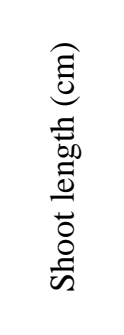 & 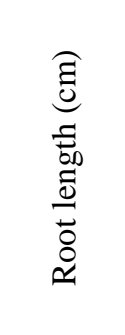 & 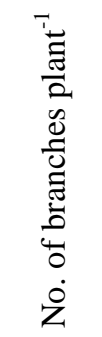 & 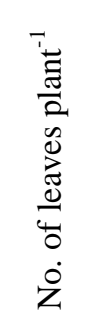 & 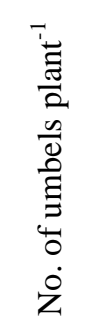 & 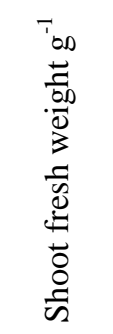 & 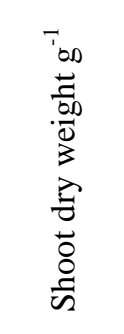 \\
\hline \multirow{4}{*}{ 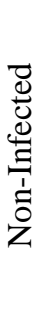 } & $\mathrm{C}$ & $20.00 \mathrm{~d}$ & $7.250 \mathrm{de}$ & $4.00 \mathrm{ab}$ & $7.50 \mathrm{a}$ & $3.75 \mathrm{ab}$ & $1.600 \mathrm{a}$ & $0.5120 \mathrm{~b}$ \\
\hline & $\mathrm{AM}$ & $24.00 \mathrm{ab}$ & $9.625 \mathrm{~b}$ & $4.25 \mathrm{a}$ & $7.25 \mathrm{a}$ & $3.75 \mathrm{ab}$ & $1.683 \mathrm{a}$ & $0.5552 \mathrm{ab}$ \\
\hline & GBTV & $23.75 \mathrm{ab}$ & $8.750 \mathrm{bc}$ & $4.00 \mathrm{ab}$ & $7.50 \mathrm{a}$ & $3.75 \mathrm{ab}$ & $1.743 \mathrm{a}$ & $0.5750 \mathrm{ab}$ \\
\hline & $\begin{array}{l}\text { AM + } \\
\text { GBTV }\end{array}$ & $24.50 \mathrm{a}$ & $11.00 \mathrm{a}$ & $4.25 \mathrm{a}$ & $7.50 \mathrm{a}$ & $4.00 \mathrm{a}$ & $1.750 \mathrm{a}$ & $0.5950 \mathrm{a}$ \\
\hline \multirow{5}{*}{ 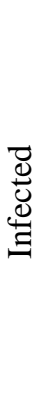 } & $\mathrm{P}$ & $17.30 \mathrm{e}$ & $5.550 \mathrm{f}$ & $2.50 \mathrm{c}$ & $6.25 \mathrm{~b}$ & $2.50 \mathrm{~b}$ & $0.800 \mathrm{~d}$ & $0.2240 \mathrm{~d}$ \\
\hline & $\mathrm{P}+\mathrm{AM}$ & $22.25 b c$ & $8.125 \mathrm{cde}$ & $3.25 \mathrm{bc}$ & $7.50 \mathrm{a}$ & $3.00 \mathrm{ab}$ & $1.045 \mathrm{c}$ & $0.3135 \mathrm{c}$ \\
\hline & $\mathrm{P}+\mathrm{GBTV}$ & $22.45 \mathrm{abc}$ & $8.700 \mathrm{bcd}$ & $4.00 \mathrm{ab}$ & $7.75 \mathrm{a}$ & $3.50 \mathrm{ab}$ & $1.083 \mathrm{c}$ & $0.3248 \mathrm{c}$ \\
\hline & $\mathrm{P}+\mathrm{F}$ & $20.75 \mathrm{~cd}$ & $7.000 \mathrm{e}$ & $3.25 \mathrm{bc}$ & $7.00 \mathrm{ab}$ & $3.00 \mathrm{ab}$ & $0.985 \mathrm{~cd}$ & $0.3054 \mathrm{c}$ \\
\hline & $\begin{array}{c}\mathrm{P}+\mathrm{AM}+ \\
\text { GBTV }\end{array}$ & $23.00 \mathrm{ab}$ & 8.000 cde & $3.50 \mathrm{ab}$ & $7.75 \mathrm{a}$ & $3.25 \mathrm{ab}$ & $1.345 \mathrm{~b}$ & $0.3821 \mathrm{c}$ \\
\hline
\end{tabular}

Means followed by the different letter within each column are significantly different using Duncan's Multiple Range Test at P-value of $\leq .0 .05$

Where; $\mathrm{C}=$ negative control, $\mathrm{AM}=$ arbuscular mycorrhiza, GBTV = granular formulated $T$. viride, $\mathrm{P}=$ Fusarium oxysporum pathogen and $\mathrm{F}=$ Recommended fungicide.

The efficacy of Trichoderma species as biofertilizers has gained support from multiple reports indicating that when applied to soil, seeds or plant surfaces, it increases the solubility of nutrients as well as the nutrient uptake capacity of the root. This benficial effect was explained by the capacity of Trichoderma fungus to

Egypt. J. Phytopathol., Vol. 47, No. 1 (2019) 
modulate root architecture and/or through the production of compounds that increase nutrients availability, such as siderophores and organic acids (Singh, et al., 2014 and Contreras-Cornejo, et al., 2015). Phytohormones i.e., Auxins, cytokinins, gibberellins, ethylene and abscisic acid produced by Trichoderma spp. have been shown to play important roles in bioagent fungus-plant interactions including plant root architecture, augmenting plant biomass and enhancing of plant resistance to biotic and abiotic stress (Guzmán-Guzmán et al., 2019). In this connection, Martínez-Medina et al. (2014) reported the positive relation between the bio-control ability of Trichoderma spp. against Fusarium oxysporum in melon plants and their induction of the phytohormones.

\section{Mycorrhizal root colonization}

Effect of the tested treatments on mycorrhizal colonization on the cumin plant was investigated. Data in Figs. (2 and 3) indicate considerable differences among treatments in the mycorrhizal colonization of cumin roots. The single inoculation with AM was the most effective treatment in increasing level of mycorrhizal root colonization under infection conditions by FOC pathogen (73.50\%). However, treatments with AM+GBTV mixture came at the second rank (60\%). The same pronounced increase in the level of mycorrhizal root colonization compared with non-infected treatments was recorded by a sole AM application, being as $90 \%$, followed by the dual inoculation with AMF+GBTV (66.67\%).

Colonized cumin roots in the presence and absence of Fusarium infection were found to have different mycorrhizal structures i.e., hyhae, spores, vesicles and arbuscules. AM established faster, then enhanced growth of cumin roots. Cumin plants may have a rhizosphere that stimulates colonization and subsequent functioning of AMF species by production of exudates. In this connections, physicochemical soil factors e.g., clay content, total nitrogen and electrical conductivity, as well as phytobiont species, and seasonal climate were reported to have a positive correlation with AMF spore density (Silva-Flores et al. 2019). These above results are in agreement with the finding of Mwangi et al. (2009) who reported that colonization by AMF and spore density were reduced in combinations of $T$. viride + AMF and T. virens + AMF treated pots as compared to AMF alone treated pots. Similar results were obtained by Tanwar et al., (2013) who reported a higher AM colonization and spore number of tomato root by sole inoculation of AMF treatment, compared to its dual inoculation with $T$. viride. But, this decrease has no effect on biocontrol efficiency of bioagents. According to Rousseau et al. (1996), antagonistic activity of Trichoderma against AMF is a complex mechanism involving production of antibiotic substances and cell wall degrading enzymes followed by AMF spore wall penetration. These results are also in accordance with Wyss et al. (1992) who reported that Trichoderma decreased colonization of soybean roots by G. mosseae due to elevated levels of the plant defence compound glyceollin, which is antimicrobial phytoalexin. 


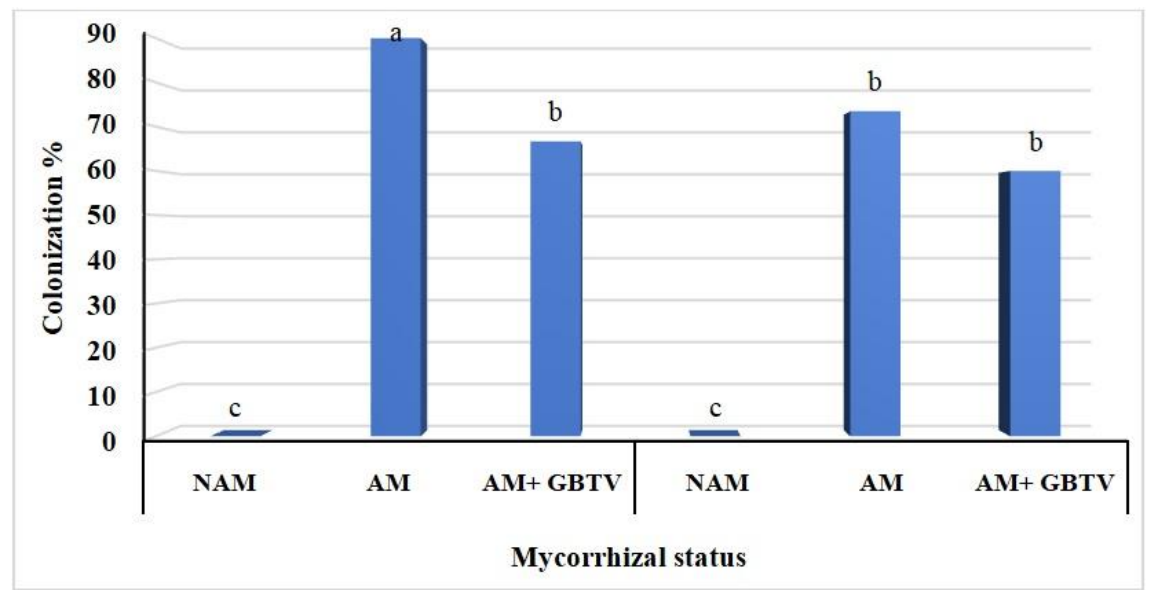

Fig. (2): Mycorrhizal colonization of cumin roots as affected by GBTV and/or AM treatments under greenhouse and $F$. oxysporum infection.

Means followed by the different letter within each column are significantly different using Duncan's Multiple Range Test at $P$ value of $\leq .0 .05$

Where; $\mathrm{C}=$ negative control, $\mathrm{NAM}=$ non-mycorrhiza, $\mathrm{AM}=$ arbuscular mycorrhiza, GBTV $=$ granular formulated $T$. viride and $\mathrm{P}=$ Fusarium oxysporum pathogen
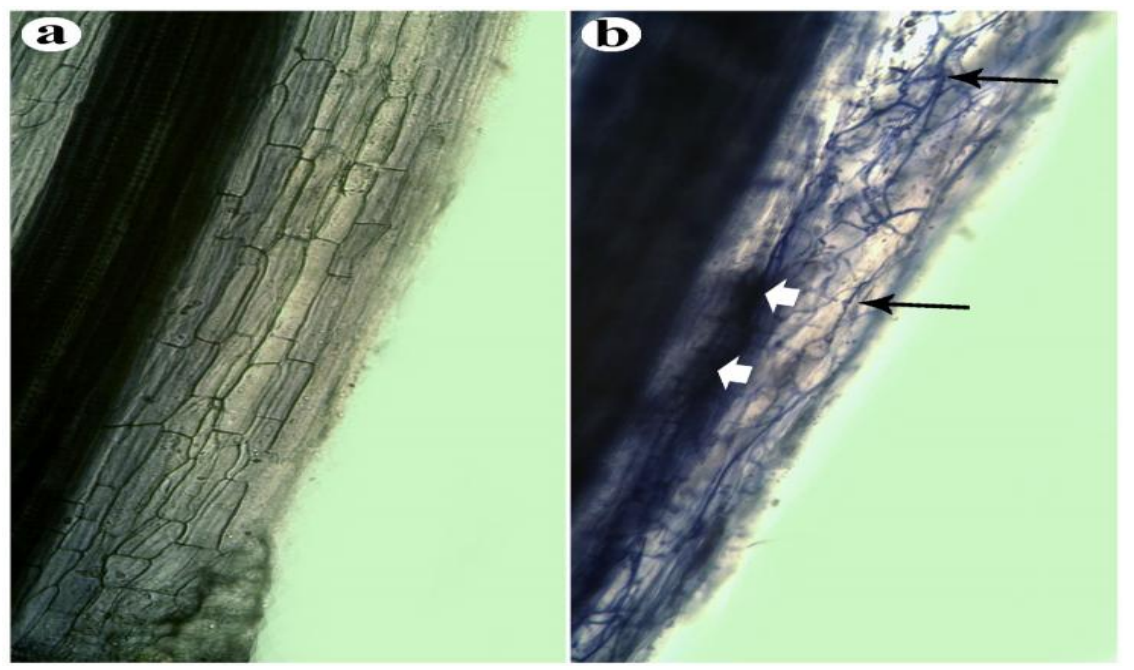

Fig. 3: Light micrographs of cumin roots colonized with AM ( $\times 400)$, (a) nonmycorrhizal root, and (b) colonized root displaying the typical mycorrhizal structures intraradical hyphae (arrows) and arbuscules (arrowheads).

Egypt. J. Phytopathol., Vol. 47, No. 1 (2019) 
Physiological parameters of cumin as affected by GBTV and/or AM treatments

The physiological response of cumin plants in terms of total polyphenols, polyphenoloxidase, peroxidase enzymes and photosynthetic pigments contents in all investigated GBTV and/or AM treatments is displayed in Table (4). In the presence of FOC, a significant increase was recorded in total phenol contents as response to sole GBTV treatment $\left(197.0 \mathrm{mg} /\right.$ catechol $\left.100 \mathrm{~g}^{-1} \mathrm{FW}\right)$. Treatment of single AM came after (187.40 mg catechol $\left.100 \mathrm{~g}^{-1} \mathrm{FW}\right)$, in comparison to untreated-infected control $\left(170.91 \mathrm{mg}\right.$ catechol $\left.100 \mathrm{~g}^{-1} \mathrm{FW}\right)$. On the other hand, the peroxidase activity was sharply increased to eight-fold by a single AM application (81.00 Unit. $\mathrm{min}^{-1} \mathrm{~g}^{-}$ ${ }^{1}$ ) as compared to untreated-infected control (10.2 Unit. $\mathrm{min}^{-1} \mathrm{~g}^{-1}$ ) Polyphenoloxidase increased also by AM+GBTV combination or AM application alone (2.84 and 3.08 Unit. $\min ^{-1} \mathrm{~g}^{-1}$, respectively) as compared to fungicide treatment $\left(0.27\right.$ Unit. $\mathrm{min}^{-1} \mathrm{~g}^{-}$ ${ }^{1}$ ) and infected control (0.40 Unit. $\left.\mathrm{min}^{-1} \mathrm{~g}^{-1}\right)$. Without infection stress, similar increases were recorded in both peroxidase and polyphenoloxidase activities (211.6 and 6.44 Unit. $\mathrm{Min}^{-1} \mathrm{~g}^{-1}$, respectively) by a single AM application as compared to negative control (36.00 and $1.92 \mathrm{Unit}^{\mathrm{Min}} \mathrm{M} \mathrm{g}^{-1}$, respectively). It is well known that total phenol, peroxidase (POD) and polyphenoloxidase (PPO) are physiological parameters reflecting the health condition of the plant. During symbiosis interactions between plant roots and mycorrhizal fungi, many reports emphasized that an induced resistance mechanism rather than increased tolerance or other effects plays a major role in plant defense against a broad spectrum of pathogens (Abdel-Fattah et al. 2011; Pérez-de-Luque et al. 2017; Mauch-Mani et al. 2017; Zhang et al. 2018). In this connection, Abdel-Fattah et al. (2011) investigated the biocontrol activity of a mixture of AM fungi against Rhizoctonia root rot of common bean, caused by Rhizoctonia solani, under greenhouse assay. Plant root colonization by AM fungi minimized both disease severity and disease incidence of the target pathogen as well as significantly increased growth parameters, yield parameters and mineral nutrient concentrations. Also, it exhibited different physical and biochemical changes including improvement plant nutrition, improvement plant growth, increase in cell wall thickening, cytoplasmic granulation, and accumulation of total phenols and induction of the defense-related enzymes (phenylalanine ammonia-lyase, POD and PPO) in plant root. Also, Zhang et al. (2018) evaluated the symbiotic efficiency of Rhizophagus irregularis CD1 on plant growth promotion and Verticillium wilt disease over a range of 3 to $94 \%$ in 17 cotton varieties. In this respect, Rhizophagus irregularis colonization sharply inhibited the symptom development of Verticillium dahliae pathogen associated with the highest-symbiotic efficiency variety (Lumian 1) and more strongly elevated the expression of pathogenesis-related genes and lignin synthesis-related genes.

Concerning photosynthetic pigments, generally, the presence of the pathogen markedly reduced the content of photosynthetic pigments of cumin leaves. Under infection stress, soil treated with all biotreatments alleviated the harmful effect of the pathogen, in which the highest significant increase of total Chls (38.90 and 46.03\%, 
respectively) were recorded by sole AM and GBTV applications. Concerning carotenoids, the majority of biotreatments showed in significant increase compared to infected control and recommended fungicide treatments. Without infection stress, the mixture of AM+GBTV presented the highest significant increase of total Chls (45.4\%), followed by a single AM or GBTV treatments (21.23 and 24.97\%, respectively) as compared to the negative control. These results complies with Tanwar et al. (2013) who reported a significant increase of photosynthesis, chlorophyll content and nutrient content in tomato plants as a response to T. viride and/or AM treatments.

It is well established that the chlorophyll content is a good parameter reflecting the health condition of the plant, it enhances the efficacy of photosynthetic with a better potential for disease resistance and decrease in photophosphorylation rate usually occurring after infection (Amaresh and Bhatt, 1998). The acquisition of carbon is strongly modulated by the surface area of photosynthesizing leaves; hence, understanding leaf area development is germane to the efforts to increase yield (Kays and Nottingham, 2008).

Table (4): Physiological characteristics of cumin as affected by GBTV and/or AM treatments under greenhouse and $F$. oxysporum infection

\begin{tabular}{|c|c|c|c|c|c|c|c|}
\hline \multirow[b]{2}{*}{ Treatment } & \multirow{2}{*}{\begin{tabular}{|l} 
Total phenols \\
(100mg GAG \\
$\mathrm{g}^{-1}$ F.W.)
\end{tabular}} & \multirow{2}{*}{$\begin{array}{c}\text { Peroxidase } \\
\text { (Unit. Min } \\
\left.\mathrm{g}^{-1}\right)\end{array}$} & \multirow{2}{*}{$\begin{array}{c}\text { Polyphenol } \\
\text { oxidase (Unit. } \\
\operatorname{Min}^{-1} \mathrm{~g}^{-1} \text { ) }\end{array}$} & \multicolumn{4}{|c|}{ Photosynthetic pigments $\left(\mathrm{mg} \mathrm{g}^{-1} \mathrm{~F} . \mathrm{W}\right)$} \\
\hline & & & & C & Chl b & Chls & Carotenoids \\
\hline $\mathrm{C}$ & 16 & $36.00 \mathrm{f}$ & $d$ & $0.8961 \mathrm{~d}$ & $0.4234 \mathrm{ab}$ & $1.320 \mathrm{c}$ & $0.3328 \mathrm{ab}$ \\
\hline AM & $173.75 \mathrm{~cd}$ & 211.6a & $6.44 \mathrm{a}$ & $1.1311 b c$ & $0.4692 \mathrm{a}$ & $1.6003 b$ & $0.3333 \mathrm{ab}$ \\
\hline GBTV & $170.92 \mathrm{cde}$ & $120.4 \mathrm{c}$ & $1.40 \mathrm{cde}$ & $1.2361 \mathrm{ab}$ & $0.4135 \mathrm{abc}$ & $1.6496 b$ & $0.3439 a$ \\
\hline $\begin{array}{l}\text { AM + } \\
\text { GBTV }\end{array}$ & 166. & b & 1.9 & 1 & 0. & 1.9 & 0.3 \\
\hline $\mathrm{P}$ & $170.91 \mathrm{cde}$ & $10.20 \mathrm{~h}$ & $0.40 \mathrm{e}$ & $6 e$ & $0.2839 \mathrm{bcd}$ & $0.8364 \mathrm{e}$ & $0.3140 \mathrm{abc}$ \\
\hline $\mathrm{P}+\mathrm{AM}$ & $187.40 \mathrm{~b}$ & $81.00 \mathrm{~d}$ & $3.08 \mathrm{~b}$ & $0.8810 \mathrm{~d}$ & $0.2808 \mathrm{bcd}$ & $1.1618 \mathrm{~cd}$ & $0.2975 \mathrm{abc}$ \\
\hline $\mathrm{P}+\mathrm{GBTV}$ & 197.01a & $47.60 \mathrm{e}$ & $1.04 \mathrm{de}$ & $0.9376 \mathrm{~cd}$ & $0.2838 \mathrm{bcd}$ & 1.22 & $0.3441 \mathrm{a}$ \\
\hline $\mathrm{P}+\mathrm{F}$ & $172.00 \mathrm{cde}$ & $43.00 \mathrm{e}$ & $0.27 \mathrm{e}$ & $0.7889 \mathrm{de}$ & $0.2069 \mathrm{~d}$ & $0.9458 \mathrm{cde}$ & $0.2674 \mathrm{c}$ \\
\hline $\begin{array}{c}\mathrm{P}+\mathrm{AM}+ \\
\text { GBTV }\end{array}$ & $175.23 \mathrm{c}$ & $20.00 \mathrm{~g}$ & $2.84 b c$ & $0.8481 \mathrm{~d}$ & $0.2544 \mathrm{~cd}$ & $1.1025 \mathrm{cde}$ & $0.2836 b c$ \\
\hline
\end{tabular}

Means followed by the different letters within each column are significantly different using Duncan's Multiple Range Test at $P$ value of $\leq .0 .05$

Where; $\mathrm{C}=$ negative control, $\mathrm{AM}=$ arbuscular mycorrhiza, $\mathrm{GBTV}=$ granular formulated $T$. viride, $\mathrm{P}=$ Fusarium oxysporum pathogen and $\mathrm{F}=$ Recommended fungicide

Egypt. J. Phytopathol., Vol. 47, No. 1 (2019) 
Greenhouse evaluation of GBTV and/or AM treatments on the disease development of cumin

Evaluation of GBTV and/or AM treatments under epiphytic conditions for their action on FOC indicates a considerable difference in the disease rating of cumin plants (Fig. 4). In this connection, control treatment showed obvious disease symptoms of seed rot, being $17.75 \%$, with infected plants being $28.0 \%$. Soil treated with the dual inoculation of AM+GBTV showed the highest protection levels and reduced the disease mortality symptoms, to be $60.83 \%$ without significant differences between the chemical fungicides (62.67\%). Treatments of a sole GBTV came next in this respect, recording $55.76 \%$, followed by a single AM application, being $47.0 \%$ compared to infected control treatment.

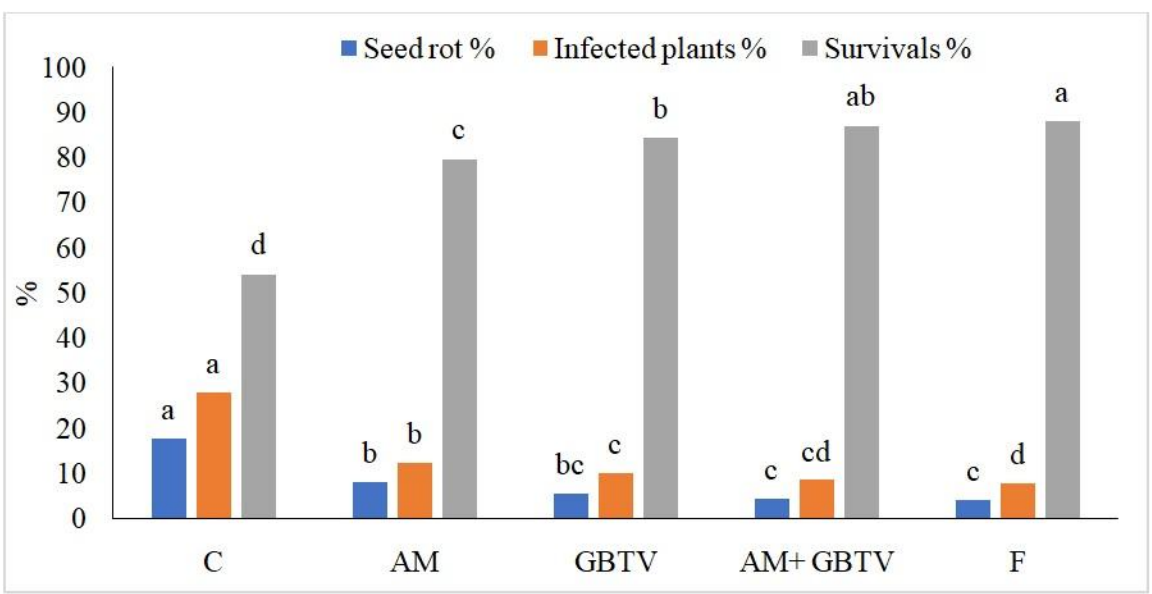

Fig. (4): Disease rating of cumin wilt affected by GBTV and/or AM treatments under greenhouse conditions

Means followed by the different letter within each column are significantly different using Duncan's Multiple Range Test at Pvalue of $\leq .0 .05$

Where; $\mathrm{C}=$ control, $\mathrm{AM}=$ arbuscular mycorrhiza, GBTV $=$ granular formulated $T$. viride and $\mathrm{F}=$ Recommended fungicide

Singh et al. (2007) found that seed treatment with T. harzianum formulation resulted in good control of wilt and gave higher yield. Deepak et al. (2008) indicated that when the bioagents ( $T$. viride and $T$. harzianum) were applied in combination with NPK and plant leaves powder (Datura stramonium, Azadrichta indica and Lantana camera) at different quantities, it resulted in better control of cumin wilt incidence over the individual treatments. Sharma et al. (2011) observed the effect of bio-priming with antagonistic microflora on wilt incidence of cumin. They found that talc-based formulation of $T$. viride was the best, followed by Aspergillus versicolor, T. harzianum and Pseudomonas fluorescens. Numerous Trichoderma 
isolates have been isolated from cumin rhizosphere soils which have shown antagonistic activity against cumin wilt pathogen $F$. oxysporum f.sp. cumini (Sharma et al. 2012). The isolates of T. koningiopsis, T. asperllum and T. harzianum were identified as potential bioagents in reducing wilt incidence under field conditions. Seed dressing and soil application with Trichoderma viride, Trichoderma harzianum, and Pseudomonas fluorescens lowered wilt disease incidence in cumin. Chawla and Gangopadhyay (2013) found that seed treatment with Psuedomonas fluorescens $+T$. harzianum resulted in least disease incidence and better growth, yield contributing parameters and higher seed yield. Also, Bhatnagar et al. (2013) found that seed treatment with a combination of carbendazim, $T$. viride and neem seed kernel extract (10\%) resulted in minimum wilt incidence $(7.2 \%)$. The above results are in agreement with Mwangi et al. (2009) who reported a pronounced increase in growth of tomato, napier and tea plants due to roots colonization by individual and co-inoculation of $T$. harzianum PS2+AMF. These findings also comply with Dehariya et al. (2015) who asserted that co-inoculation of $\mathrm{T}$. harzianum + AMF gave significant wilt disease reduction and growth promoted of pigeon pea plant. In this connection, the dual inoculation by $T$. harzianum + AMF, followed by single AMF treatments showed the maximum significant increase in $\mathrm{P}$ uptake as compared to untreated infected control with Fusarium udum pathogen.

Field evaluation of GBTV and/or AM treatments on the performance of cumin plants

Data (Table 5) indicate that significant variations were recorded in growth parameters on cumin plants as a response to GBTV and/or AM treatments. Soil treated by AM+GBTV combination or a single AM exhibited the highest increase of all plant growth characters (plant height, branches and numbers of umbels plant ${ }^{-1}$ and dry weight plant ${ }^{-1}$ ), compared to control treatment. GBTV treatment ranked the third, followed by that treated with chemical fungicide compared with the control. In respect to yield component, no significant differences were observed among all biotreatments in increasing number of umbels plant ${ }^{-1}$. However, combined treatment of AM+GBTV or a single AM showed the maximum significant increase in weight of seed plant ${ }^{-1}$ (2.146 and $2.063 \mathrm{~g} \mathrm{plant}^{-1}$, respectively) and weight of 1000 seeds (3.074 and 2.839g plant ${ }^{-1}$, respectively), followed by fungicide treatment and a single GBTV as compared to control.

The application of GBTV and AM singly or combined significantly lowered seed rot, infected plants and increased survival cumin plants under field condtions (Fig 4). Field results confirmed the greenhouse results. Similar trends of these results were observed in the findings of Tawfik and Allam (2004), they reported that the use of $T$. harzianum alone or in combination with water priming tend to produce a high cumin seed yield per plant, which was associated with a decreased percentage of infection. In this respect, a significant positive correlation coefficient was found between the seed yield and each of the number of main and secondary branches, the number of umbels and the weight of the mature dry plants. These results are also in accordance with Al-Askar et al. (2014) and Ezzat et al. (2015) who reported that the Egypt. J. Phytopathol., Vol. 47, No. 1 (2019) 
combination of AM+hydroquinone (HQ) or AM+ Tichoderma spp. (T) gave significant disease reduction in incidence, improved plant growth and yield and enhanced the tuber quality more than the individual agent alone of Jerusalem artichoke plant, under greenhouse and field conditions.

The important component of this investigation was to use the sole and combinations of locally available bioagents: Trichoderma viride formulation (GBTV) and arbuscular mycorrhizal fungi (AM) for biological control of cumin wilt. These pronounced positive effects on the vegetative growth parameters of cumin plants may be returned to the fact that, AMF provide soil mineral nutrients (mainly phosphorus and nitrogen), water, and enhance the plant immunity against the attack of Fusarium wilt disease as alternative control instead of fungicide.

Table (5): Growth and yield of cumin as affected by the tested GBTV and/or AM treatments under field conditions

\begin{tabular}{lccccccc}
\hline Treatment & $\begin{array}{c}\text { Shoot } \\
\text { length } \\
(\mathrm{cm})\end{array}$ & $\begin{array}{c}\text { Root } \\
\text { length } \\
(\mathrm{cm})\end{array}$ & $\begin{array}{c}\text { Branches } \\
\text { number } \\
\text { plant }^{-1}\end{array}$ & $\begin{array}{c}\text { Dry } \\
\text { weight } \\
\left(\mathrm{g}^{-1}\right)\end{array}$ & $\begin{array}{c}\text { Number } \\
\text { of } \\
\text { umbels } \\
\text { plant }^{-1}\end{array}$ & $\begin{array}{c}\text { Weight } \\
\text { of seeds }_{\text {plant }}{ }^{-1}\end{array}$ & $\begin{array}{c}\text { Weight } \\
\text { of } 1000 \\
\text { seeds } \\
\left(\mathrm{g}^{-1}\right)\end{array}$ \\
\hline $\mathrm{C}$ & $29.38 \mathrm{~d}$ & $17.25 \mathrm{c}$ & $4.75 \mathrm{~b}$ & $3.025 \mathrm{~d}$ & $16.75 \mathrm{c}$ & $1.256 \mathrm{~d}$ & $1.254 \mathrm{c}$ \\
$\mathrm{AM}$ & $37.00 \mathrm{~b}$ & $19.63 \mathrm{ab}$ & $6.00 \mathrm{a}$ & $3.813 \mathrm{a}$ & $27.50 \mathrm{a}$ & $2.063 \mathrm{ab}$ & $2.839 \mathrm{ab}$ \\
$\mathrm{GBTV}$ & $35.00 \mathrm{c}$ & $18.75 \mathrm{~b}$ & $5.50 \mathrm{ab}$ & $3.570 \mathrm{~b}$ & $28.00 \mathrm{a}$ & $1.960 \mathrm{bc}$ & $2.722 \mathrm{~b}$ \\
$\mathrm{AM+GBTV}$ & $39.00 \mathrm{a}$ & $21.00 \mathrm{a}$ & $6.25 \mathrm{a}$ & $3.745 \mathrm{a}$ & $29.00 \mathrm{a}$ & $2.146 \mathrm{a}$ & $3.074 \mathrm{a}$ \\
$\mathrm{F}$ & $37.50 \mathrm{~b}$ & $17.00 \mathrm{c}$ & $5.75 \mathrm{ab}$ & $3.403 \mathrm{c}$ & $22.75 \mathrm{~b}$ & $1.866 \mathrm{c}$ & $2.528 \mathrm{~b}$ \\
\hline
\end{tabular}

Means followed by the different letters within each column are significantly different using Duncan's Multiple Range Test at $\mathrm{P}$ value of $\leq .0 .05$

Where; $\mathrm{C}=$ control, $\mathrm{AM}=$ arbuscular mycorrhiza, $\mathrm{GBTV}=$ granular formulated $T$. viride and $\mathrm{F}=$ Recommended fungicide

\section{Conclusions}

Our results verified the ability of AMF + GBTV formulation as safe, environment-friendly and effective means to fight $F$. oxysporum f. sp. cumini, the causal agent of wilt in cumin plant, as well as improve cumin plant growth and its productivity. On the other side, they can be beneficial for reducing the production cost of cumin crops and lowering excessive using of synthetic fungicides as well as biofertilizers, and that helps for decreasing of environmental pollution. 


\section{R e f e r e n c es}

Abdel-Fattah, G.M.; El-Haddad, S.A.; Hafez, E.E and Rashad, S.A. 2011. Induction of defense responses in common bean plants by arbuscular mycorrhizal fungi. Microbiol. Res., 166(4): 268-281.

Abhiram, P. and Masih, H. 2018. In vitro antagonism of Trichoderma viride against Fusarium oxysporum strains. J. of Pharmacognosy and Phytochem., 7(2): 28162819.

Aghnoom, R.; Falahati-Rastegar, M. and Jafarpour, B. 2002. Comparison of chemical and biological control of cumin wilt (Fusarium oxysporum f. sp. cumini) in laboratory and greenhouse conditions. Iran. J. Agril. Sci., 30(3): 619630.

Amaresh, C. and Bhatt. R.K. 1998. Biochemical and physiological response to salicylic acid in reaction to systemic acquired resistance. Photosynthetica, 35: 255-258.

Bell, D.K., Well, H.D. and Markhem, C.R. 1982. In vitro antagonism of Trichodema species against six fungal plant pathogens. Phytopathology, 72: 379-382.

Bharti, V.S.; Dotaniya, M.L.; Shukla, S.P.; Yadav, V.K. 2017. Managing soil fertility through microbes: prospects, challenges and future strategies. In: J. S. Singh and G. Seneviratane (Eds.), Agro-Environmental Sustainability. 2017., pp: 81-111. Springer International Publishing AG.

Bhatnagar, K.; Tak, S.K.; Sharma, R.S.; Majumdar, V.L. and Meena R.L. 2013. Management of cumin wilt caused by Fusarium oxysporum f.sp. cumini through chemical and biological agents. Indian Phytopath., 66: 101-102.

Bissett, J. 1991. A revision of the genus Trichoderma. Intrageneric classification. Can. J. Bot., 69: 2357-2372.

Blainski, A.; Lopes, G.C. and de Mello, J.C.P. 2013. Application and analysis of the folin ciocalteu method for the determination of the total phenolic content from Limonium brasiliense L. Molecules, 18: 6852-6865.

Booth, C. 1977. The genus Fusarium. Commonwealth Mycological Institute, Kew, Surrey, England.

Chawla, N. and Gangopadhyay, S. 2013. Performance of bioagents in management of wilt (Fusarium oxysporum f.sp. cumini) and their resultant effect on growth and productivity of cumin (Cuminium cyminium) under field conditions of arid region of Rajasthan. Indian Journal of Agricultural Sciences, 83: 561-565.

Chen, M.; Arato, M.; Borghi, L.; Nouri, E. and Reinhardt, D. 2018. Beneficial services of arbuscular mycorrhizal fungi-from ecology to application. Frontiers in Plant Sci. 9: 1270.

Egypt. J. Phytopathol., Vol. 47, No. 1 (2019) 
Contreras-Cornejo, H.A.; Macı'as-Rodrı'guez, L.; Vergara, A.G. and Lo'pez-Bucio, J. 2015. Trichoderma modulates stomatal aperture and leaf transpiration through an abscisic acid-dependent mechanism in Arabidopsis. J. Plant Growth Regul., 34: 425-432.

CoStat. 2005. Cohort Software. 798 Lighthouse Ave., PMB 320 Monterey, USA.

Deepak, P.; Saran, L. and Lal, G. 2008. Control of wilt and blight diseases of cumin through antagonistic fungi under in vitro and field conditions. Notulae Botanicae Horti Agrobotanici Cluj-Napoca, 36(2): 91-96.

Dehariya, K.; Shukla, A.; Sheikh, I. A. and Vyas, D. 2015. Trichoderma and arbuscular mycorrhizal fungi based biocontrol of Fusarium udum Butler and their Growth promotion effects on pigeon pea. J. of Agric. Sci. and Technol., 17: 505-517.

Dhingra, O.D. and Sinclair, J.B. 1995. Basic Plant Pathology Methods. CRS Press Inc Boca Raton, Florida, 335 pp.

Domsch, K.H.; Gams, W. and Anderson, T.H. 1980. Compendium of Soil Fungi. Vols. 1, 2. Academic Press, New York.

Elad, Y.; Hadar, Y.; Hader, E.; Chet, I. and Henis, Y. 1991. Biological control of Rhizoctonia solani by Trichoderma harzianum in carnation. Plant Dis., 65: 675677 .

El-Gazzar, N.; El-Bakery, A.M. and Ata, A.A. 2018. Influence of some bioagents and chitosan nanoparticles on controlling maize late wilt and improving plants characteristics. Egypt. J. Phytopathol., 46(2): 243-264.

Ezzat, A.E.S., Ghoneem, K.M., Saber, W.I.A. and Al-Askar, A.A. 2015. Control of wilt, stalk and tuber rots diseases using arbuscular mycorrhizal fungi, Trichoderma species and hydroquinone enhances yield quality and storability of Jerusalem artichoke (Helianthus tuberosus L.). Egyp. J. of Biol. Pest Control, 25(1): 11-22.

Gajera, H.P.; Bambharolia, R.P.; Pate, S.V.; Khatrani T.J and Goalkiya B.A. 2012. Antagonism of Trichoderma spp. against Macrophomina phaseolina: evaluation of coiling and cell wall degrading enzymatic activities. Plant Pathol. Microbiol., 3: $2157-7471$.

Ghorbanpour, M.; Omidvari, M.; Abbaszadeh-Dahaji, P.; Omidvar, R. and Kariman, K. 2018. Mechanisms underlying the protective effects of beneficial fungi against plant diseases. Biol. Control, 117: 147-157.

Guzmán-Guzmán, P.; Porras-Torras, M.D.; Olmedo-Monfil, V. and Herrea-Estrella, A. 2019. Trichoderma species: versatile plant symbionts. Phytopathology, 109: 6-16. 
Hafez, E.E.; Abdel-Fattah, G.M.; El-Haddad, S.A. and Rashad, Y.M. 2013. Molecular defense response of mycorrhizal bean plants infected with Rhizoctonia solani. Ann. Microbiol., 63(3): 1195-1203.

Harman, G.E.; Howell, C.R.; Viterbo, A.; Chet, I. and Lorito, M. 2004. Trichoderma species-Opportunistic, avirulent plant symbionts. Nature Rev. Microbiol., 2: 4356.

Haware, M.P.; Nene, Y.L. and Natarajan, M. 1996. Survival of Fusarium oxysporum f. sp. cicer in soil in the absence of chickpea. Phytopathologia Mediterranean, 35: $9-12$.

Kays, S.J. and Nottingham, S.F. 2008. Introduction: An underutilized resource. In: Biology and chemistry of Jerusalem artichoke (Helianthus tuberosus L.) (Kays SJ, Nottingham SF, eds). CRC Press, Florida, pp. 1-5.

Kehri, H.K.; Akhtar, O.; Zoomi, I. and Pandey, D. 2018. Arbuscular mycorrhizal fungi: taxonomy and its systematics. Int. J. of Life Sci. Res., 6(4): 58-71.

Kubicek,. CP. and Harman, G.E. 2002. Trichoderma and Gliocladium (vol. I). Basic Biol., Taxon. and Gen., 1: 14-24.

Martínez-Medina, A.; Alguacil, M.D.M.; Pascual, J.A. and Van Wees, S.C.M. 2014. Phytohormone profiles induced by Trichoderma isolates correspond with their biocontrol and plant growth-promoting activity on melon plants. J. Chem. Ecol., 40: $804-815$.

Mauch-Mani, B.; Baccelli, I.; Luna, E. and Flors, V. 2017. Defense priming: An adaptive part of induced resistance. Annu. Rev. Plant Biol., 68: 485-512.

Mahmoud, N.A. 2017. Comparative Study on the Activity of Trichoderma asperellum and T. album and their role in controlling faba bean root rot and wilt diseases. Egypt. J. Phytopathol., 45(2): 183-198.

Mohamed, N.T. 2017. Evaluation of certain biocides and chemicals inducing resistance in management of cumin wilt (Fusarium oxysporum f. sp. cumini). Egypt. J. Phytopathol., 45(1): 57-69.

Monteiro, V.N.; do Nascimento Silva, R.; Steindorff, A.S.; Costa, F.T.; Noronha, E.F.; Ricart, C.A.; de Sousa, M.V.; Vainstein, M.H. and Ulhoa, C.J. 2010. New insights in Trichoderma harzianum antagonism of fungal plant pathogens by secreted protein analysis. Curr. Microbiol., 61(4): 298-305.

Mwangi, M.W.; Monda, E.O.; Okoth, S.A. and Jefwa, J.M. 2009. Effect of Trichoderma harzianum and arbuscular mycorrhizal fungi on growth in tomato (Lycopersicum esculentum Mill) seedlings, napier (Pennisetum purpureum L) and tea (Camellia sinensis L) cuttings. Trop. and Subtrop. Agroecosys., 11: 423429.

Egypt. J. Phytopathol., Vol. 47, No. 1 (2019) 
Pérez-de-Luque, A.; Tille, S.; Johnson, I.; Pascual-Pardo1, D.; Ton, J. and Cameron, D.D. 2017. The interactive effects of arbuscular mycorrhiza and plant growthpromoting rhizobacteria synergistically enhance host plant defenses against pathogens. Sci. Reports, 7: 16409.

Phillips, J.M.; and Hayman, D.S. 1970. Improved procedures for clearing roots and staining parasitic and vesicular-arbuscular mycorrhizal fungi for rapid assessment of colonization. Trans. Bri. Mycol. Soc., 55: 157-160.

Robinson, J.M. and Britz, S.J. 2000. Tolerance of a field grown soybean cultivar to elevated ozone level is concurrent with higher leaflet ascorbic acid level, higher ascorbate-dehydroascorbate redox status, and long term photosynthetic productivity. Photosyn. Res., 64(1): 77-87.

Rousseau, A.; Benhamou, N.; Chet, I. and Piché, Y. 1996. Mycoparasitism of the Extramatrical Phase of Glomus intraradices by Trichoderma harzianum. Phytopathology, 86: 434-443

Seleim, M.A.; Abo-Elyousr, K.A.; Mohamed, A.A.A. and Al-Marzoky, H.A. 2014. Peroxidase and polyphenoloxidase activities as biochemical markers for biocontrol efficacy in the control of tomato bacterial wilt. J. Plant Physiol. and Pathol., 2:1.

Sharma Y.K.; Sriram, S.; Lodha, S. K.; Ramanujam B. and Anwer M. M. 2012. Biological control of cumin wilt (Fusarium oxysporum f.sp. cumini) using Trichoderma species and other antagonists. $3^{\text {rd }}$ Global Conference Plant Pathology for Food Security, 10-13 Jan. 2012, MPUAT, Udaipur.

Sharma, Y.K.; Kant, K.; Saxena, S.N.; Anwar, M.M.; Lodha, S.K.; Sriram, S and Ramannjam, B. 2011. Effect of biopriming with antagonists on wilt and seedling growth of cumin. International J. Seed Spices, 1:56-59.

Silva-Flores, P.; Bueno, C.G.; Neira, J. and Palfner, G. 2019. Factors affecting Arbuscular Mycorrhizal fungi spore density in the Chilean Mediterranean-type ecosystem. J. Soil Sci. and Plant Nut., 19: 42-50.

Singh, H.B.; Shrivastava, S. Singh, A. and Katiyar, R.S. 2007. Field efficacy of Trichoderma harzianum application on wilt disease of cumin caused by Fusarium oxysporum f.sp.cumini. J. Biol. Control, 21:317-319.

Singh, S.P.; Singh, H.B.; Singh, D.K. and Amitava, R. 2014. Trichoderma-mediated enhancement of nutrient uptake and reduction in incidence of Rhizoctonia solani in tomato. Egyptian Journal of Biology, 16: 29-38.

Tanwar, A.; Aggarwal, A. and Panwar, V. 2013. Arbuscular mycorrhizal fungi and Trichoderma viride mediated Fusarium wilt control in tomato. Biol. Sci. and Technol., 23(5): 485-498. 
Tawfik, A.A. and Allam, A.D.A. 2004. Improving cumin production under soil infestation with Fusarium wilt pathogen: II-Field trial of different landraces and seed treatments. Ass. Univ. Bull. Environ. Res., 7(2): 47-64.

Trouvelot, A.; Kough, J.L.; and Gianinazzi-Pearson, V., 1986. Mesure du taux de mycorhization VA d'un système radiculaire recherche de methods d'estimation ayant une signification fonctionnelle. In: Gianinazzi-Pearson, V., and Gianinazzi, S. (eds): Physiological and Genetical Aspects of Mycorrhizae. INRA Publications, Paris, pp. 217-221.

Van der Heijden, M.G.A. and Sanders, I.R. (eds). 2002. Mycorrhizal ecology. Ecological studies. New York, USA: Springer-Verlag, 2002.

Verma, A.K.; Singh, R.; Choudhary, S. and Lal, G. 2018. Cultivation of dollar earning cumin crop for higher income. Acta Sci. Agri., 2(3): 46-48.

Vinale, F.; Sivasithamparam, K.; Sivasithamparam, E.L.; Ghisalberti, S.L.; Woo, M.N.; Roberta, M.; Nadia Lombardi, Alberto, P.; Michelina, R.; Stefania, L.; Gelsomina, M. and Matteo L. 2014. Trichoderma secondary metabolites active on plants and fungal pathogens. Open Mycol. J., 8: 127-139.

Watanable, T. 2002. Pictorial Atlas of Soil and Seed Fungi: Morphologies of Cultured Fungi and Key to Species. $2^{\text {nd }}$. CRC Press, Boca Raton.

Wyss, P.; Boller, T.H. and Wiemken, A. 1992. Testing the effect of biological control agents on the formation of vesicular arbuscular mycorrhiza. Plant Soil, 147: $159-162$.

Zhang, Q.; Gao, X.; Ren, Y.; Ding, X.; Qiu, J.; Li, N.; Zeng, F. and Chu Z. 2018. Improvement of Verticillium wilt resistance by applying arbuscular mycorrhizal fungi to a cotton variety with high symbiotic efficiency under field conditions. Internat. J. Molec. Sci., 19(1): 241.

Corresponding author: Ghoneem, K.M.

E-mail: khalid_ghoneem@yahoo.com

(Received 31/03/2019;

in revised form 21/04/2019)

Egypt. J. Phytopathol., Vol. 47, No. 1 (2019) 


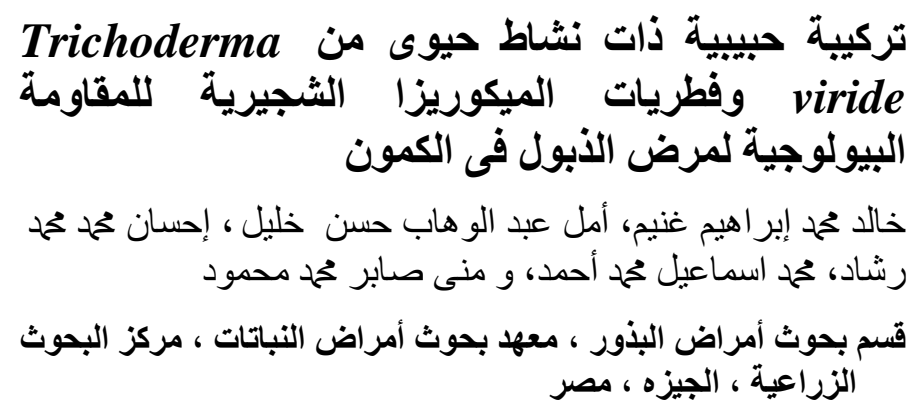

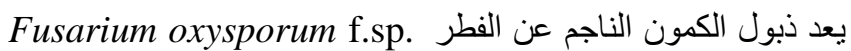

cumini

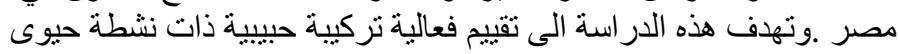

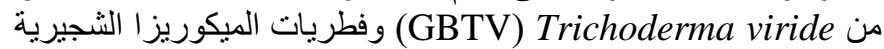

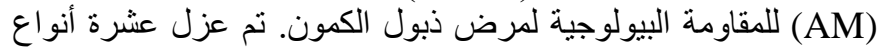

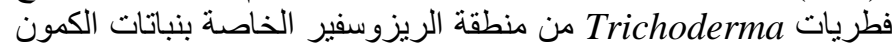

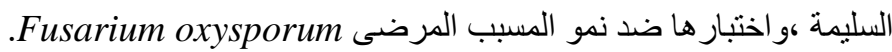
Tيث سجلت عزلات T. T. T. T.

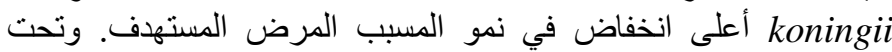

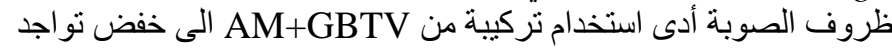

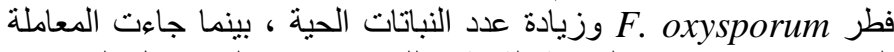

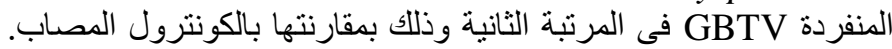

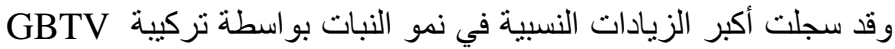

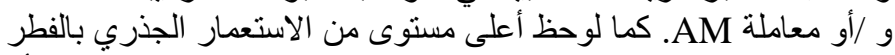

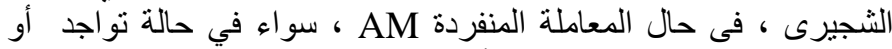

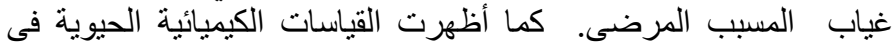

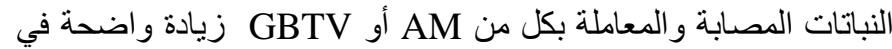

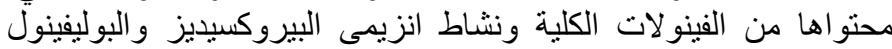

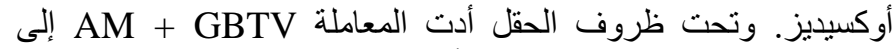
انخفاض كبير في حالات الإصابة بأعر اض الذبات الذبول وزيادة النبات الحية الكبات

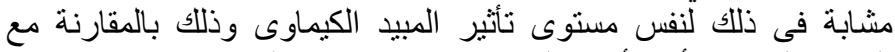

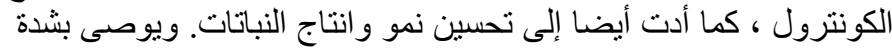

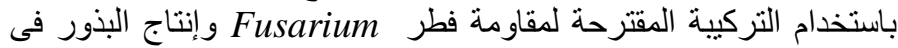

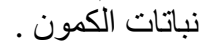

